\title{
Preliminary numerical study on groundwater system at the Hong Kong International Airport
}

\author{
Fuli Wang \\ Lincoln Ventures Ltd, Lincoln, Christchurch, New Zealand
}

Jiu J. Jiao

Department of Earth Sciences, University of Hong Kong, Hong Kong, China

\begin{abstract}
The Hong Kong International Airport was built on a man-made island. The groundwater head of the deep basal sand and gravel aquifer remains high several years after the land reclamation. The heads in different aquifers indicate an upward groundwater flow. The aim of this study is to understand the abnormally high pore water pressure in the basal aquifer. The most plausible explanation for the abnormal pressure distribution is that the groundwater flow below the airport is probably a part of the regional groundwater flow system of the Lantau Island. The airport is located at the upward discharge zone of the Lantau groundwater flow system. Based on groundwater level measurement in the airport site, a multi-aquifer model is used to simulate groundwater flow in the regional flow system. Simulation results illustrate that the high pore pressure in the basal aquifer can be generated by the regional flow system in the Lantau Island and the pore pressure is strongly affected by the seasonal variation in rainfall recharge and the hydraulic conductivity of the alluvial clay.
\end{abstract}

\section{INTRODUCTION}

Large-scale land reclamation may introduce substantial changes to original geological, hydrogeological and environmental conditions. Understanding such changes is important for properly designing and maintaining engineering projects on reclaimed land. The Hong Kong new airport was built on a largely man-made island. Several years after the reclamation, piezometers in the deep basal sand and gravel aquifer show that the groundwater head of the confined alluvial aquifer remains much higher than that in the unconfined aquifer consisting of fill materials, suggesting a significant upward flow. The aim of this study is to understand the abnormally high pore water pressure in the basal aquifer and the upward flow in the aquifer system.

A plausible explanation for the abnormal pressure distribution is that the groundwater flow below the airport is probably a part of the regional groundwater system of the Lantau Island, which has a catchment area of much larger than the airport. The airport is located at the upward discharge zone of the Lantau groundwater system. In this paper, conceptual and mathematical models are established to describe groundwater flow in the multi-aquifer system below the airport using available borehole data and groundwater piezometric measurements. Then numerical simulations are used to investigate the major factors affecting groundwater flow dynamics.

\section{BASIC GEOLOGY AND HYDROGEOLOGY OF THE AIRPORT}

The Airport is located to the north of Lantau Island (Figure 1). Its total area is about $12.5 \mathrm{~km}^{2}$, of which $75 \%$ was reclaimed from the sea. The remainder comprises the former islands of Chek Lap Kok and the Lam Chau. Detailed geologic information about the airport can be found in Plant, et al. 
(1998). A simplified geological section through A-B is shown in Figure 2. Bedrock consists of igneous intrusive and volcanic rocks in various states of weathering. It is believed that the fractured rock zone along the rockhead may be very permeable (Jiao and Nandy, 2001). Such a relatively high permeability $(\mathrm{K})$ zone is referred to as $\mathrm{HKZ}$ and is treated as a fractured aquifer in this study.

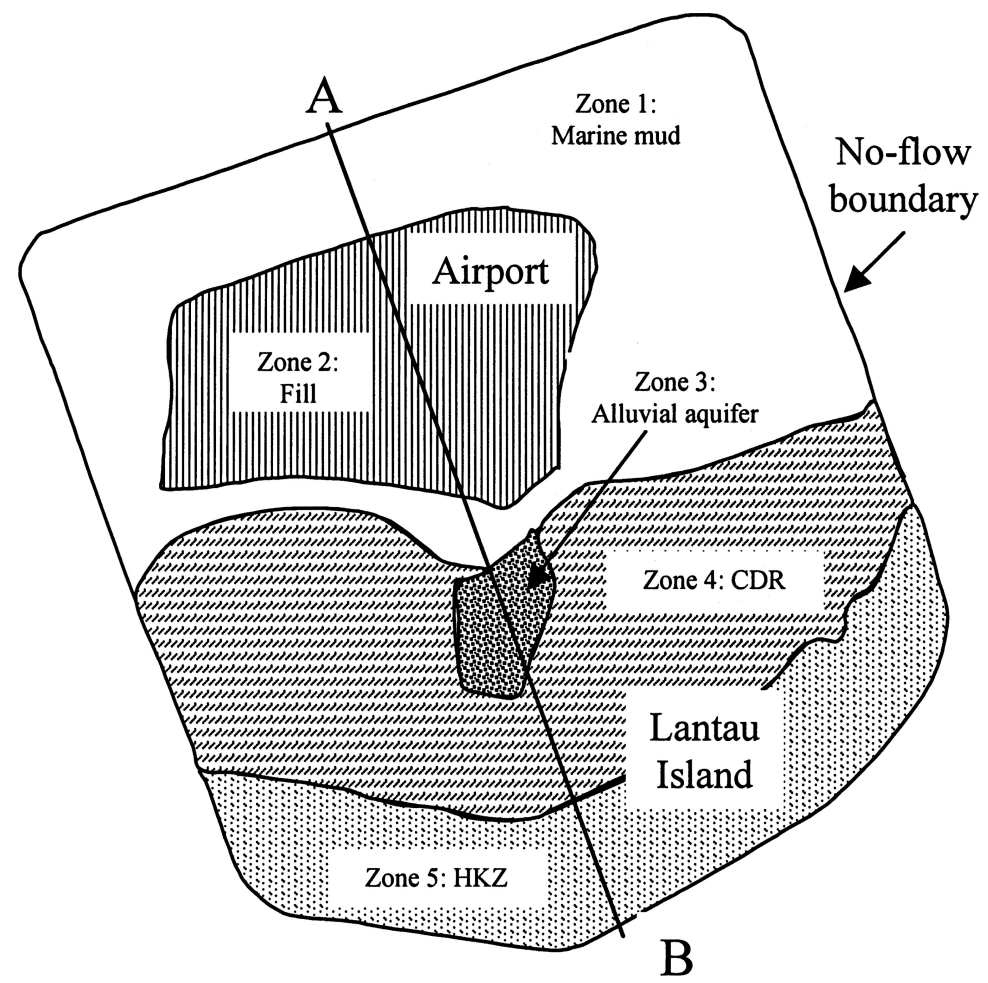

Figure 1. Model domain (plane view) and rainfall recharge zones.

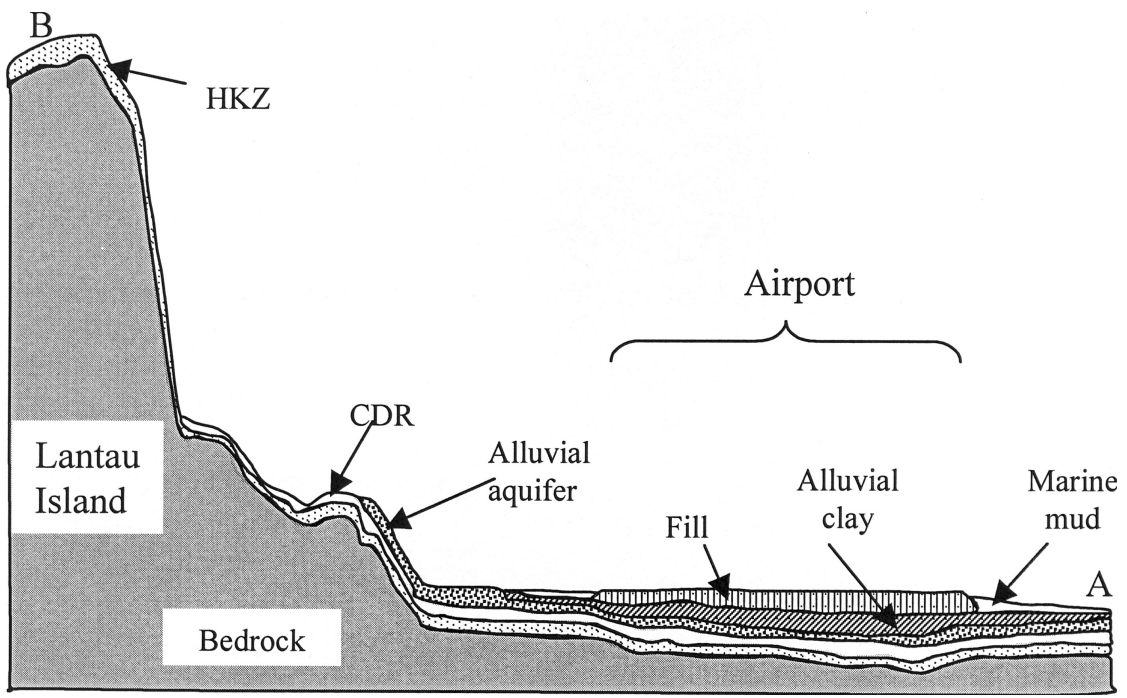

Figure 2. Geological cross section along A-B (see Figure 1 for its location) (not to scale). 
The completely decomposed rocks (CDR) are less permeable and are treated as semi-confining unit for the underlying HKZ. Next in the sequences is Chek Lap Kok Formation alluvium. The lower part of this formation consists mainly of the basal sand and gravel and the upper part consists mainly of clay. The alluvial sand and gravel become a confined aquifer. The alluvial clay above the sands provides a semi-permeable unit. The top layer in the natural sequence was predominantly very soft to soft marine muds. The mud was dredged prior to reclamation and replaced by fill materials, which consist of marine sands and rock boulders. The fill materials become a very good unconfined aquifer (Jiao and Tang, 1999).

The average annual rainfall is $2225 \mathrm{~mm}$. The mean sea level is at $1.25 \mathrm{mPD}$. Observations of groundwater head show a significant head difference between the alluvial and the fill aquifers. The average head in 18 piezometers in the fill is only $1.51 \mathrm{~m}$. However the average head in 31 piezometers in the alluvial clay and sand is $3.32 \mathrm{~m}, 1.81 \mathrm{~m}$ higher than that in the fill.

The model domain is divided into five zones (Figure 1). Zone 1 has six layers: marine mud, alluvial clay, alluvial sand and gravel, CDR, HKZ, and much less permeable bedrock. The sea is the top boundary of Zone 1 . Similarly, Zone 2 also consists of six layers, with the fill material as the topmost layer. Zone 3 has four layers: alluvial sand, CDR, HKZ and bedrock. Zone 4 has only three layers: CDR, HKZ and bedrock. Zone 5 is located at the top of hills of Lantau Island where $\mathrm{HKZ}$ is exposed to land surface and can be recharged by rainfall infiltration.

\section{MATHEMATICAL AND NUMERICAL MODELS}

The top boundary is the land surface with rainfall recharge or the seabed treated as a specified head boundary (Figure 1). The no-flow bottom boundary is set somewhere in the bedrock below the HKZ. All lateral boundaries are treated as no-flow boundaries: the south boundary is the groundwater divide in the Lantau Island; the east and west boundaries are approximately along the flow lines; and to the north, the system is buried progressively deep and lateral flow may be negligible. The governing equation for water flow under variably saturated conditions is:

$$
\nabla \cdot[K \bullet(\nabla h+\nabla z)]+q=F \frac{\partial h}{\partial t}
$$

where $K$ is the hydraulic conductivity $(\mathrm{L} / \mathrm{T}), h$ is the pressure head $(\mathrm{L}), q$ is source or sink term $\left(\mathrm{L}^{3} / \mathrm{T}\right), z$ is the vertical coordinate $(\mathrm{L}), t$ is time $(\mathrm{T})$, and $F$ is the storage coefficient expressed as:

$$
F=\alpha^{\prime} \frac{\theta}{n_{e}}+\beta^{\prime} \theta+\frac{d \theta}{d h},
$$

where $\theta$ is moisture content, $n_{e}$ is porosity, $\alpha^{\prime}$ and $\beta^{\prime}$ are the modified compressibilities of media and water, respectively.

The rainfall recharge coefficient is assigned based on the hydraulic property and types of the top soil (Table 1).

Table 1. Rainfall recharge coefficient.

\begin{tabular}{ll}
\hline Land surface material & Recharge coefficient (\%) \\
\hline Rock & 0.3 \\
CDR & 0.2 \\
Alluvial sand and gravel & 0.5 \\
Fill under vegetation & 0.4 \\
Fill under building & 0.15 \\
Fill under runway & 0.1 \\
\hline
\end{tabular}


FEMWATER, a three-dimensional finite-element model (Lin, et al., 1997), is chosen as the numerical code for solving the mathematical model. Each geologic formation is divided into at least three numerical layers. Thus the aquifer system is represented by 18 numerical layers. Each numerical layer is discretised into 1661 triangular elements.

\section{NUMERICAL SIMULATION}

Model calibration was conducted by comparing simulated groundwater heads with measured ones. Due to limited data, only hydraulic conductivities are calibrated. The target of model calibration is to minimize the difference between the average observed heads and the average simulated heads at 18 piezometers in the fill aquifer and 31 piezometers in the alluvial aquifer. Comparisons between observed and simulated heads are shown in Figure 3. The model parameters are shown at Table 2. It is evident that observed heads show larger variations than simulated ones especially in the alluvial sand aquifer, but the difference between observed and simulated average heads is reasonably small. The large difference between observed and simulated heads is due to the fact that the simulated heads are steady-state solutions and observed ones are heads measured at specific times, and that the spatial variation in the thickness and hydraulic conductivity of alluvial clay and sand layers was not well presented in the model.
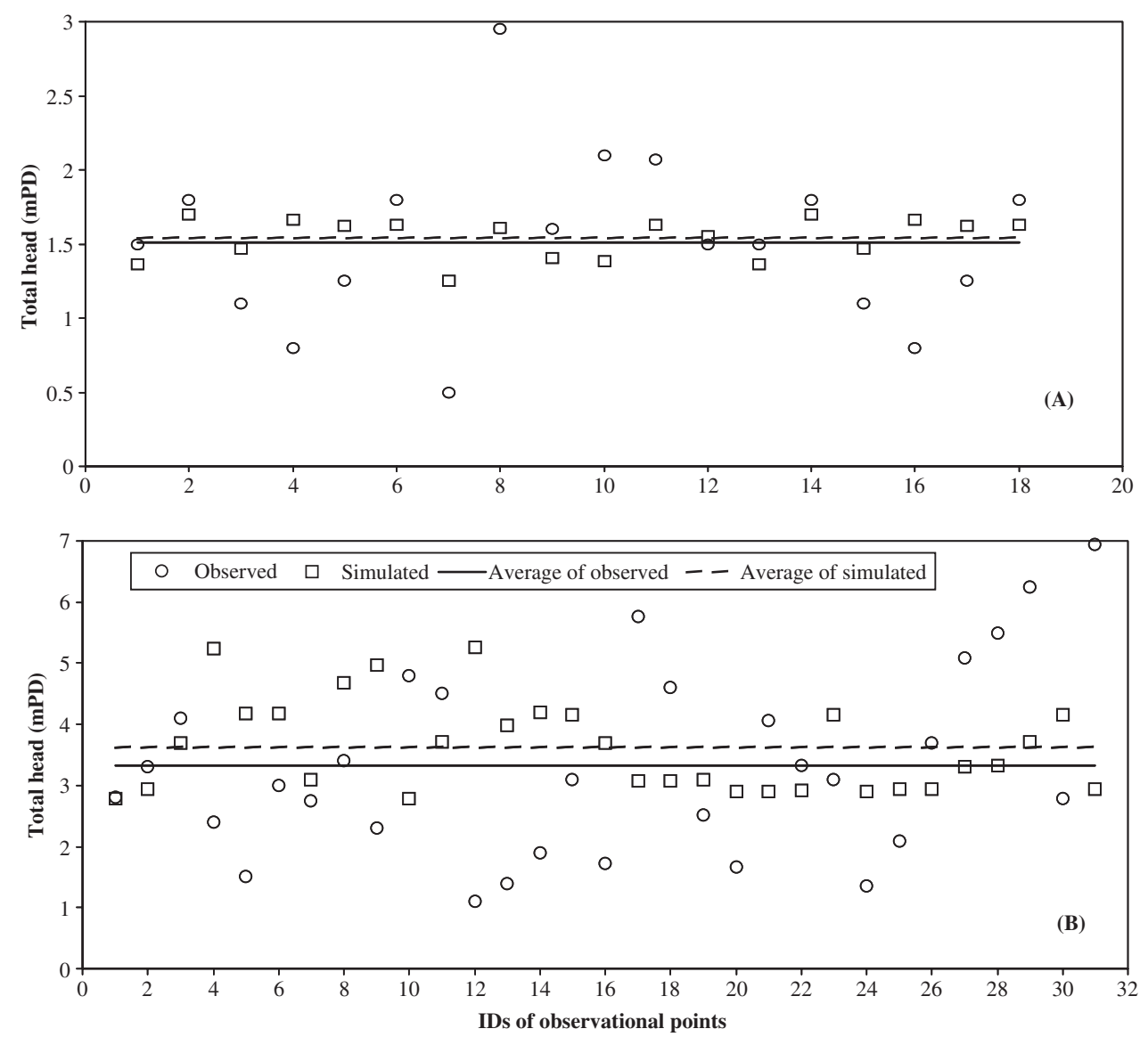

Figure 3. Comparison between observed and simulated heads in the fill (A) and alluvial (B) aquifers. 
Table 2. Values of model parameters.

\begin{tabular}{llll}
\hline Parameter & Symbol (Unit) & Value & Source \\
\hline Conductivity of fill aquifer & $\mathrm{K}_{1}(\mathrm{~m} /$ day $)$ & 172.8 & Calibrated \\
Conductivity of marine mud & $\mathrm{K}_{2}(\mathrm{~m} /$ day $)$ & 0.001 & Calibrated \\
Conductivity of alluvial clay & $\mathrm{K}_{3}(\mathrm{~m} /$ day) & 0.002 & Calibrated \\
Conductivity of alluvial aquifer & $\mathrm{K}_{4}(\mathrm{~m} /$ day) & 43.2 & Calibrated \\
Conductivity of CDR & $\mathrm{K}_{5}(\mathrm{~m} /$ day $)$ & 0.001 & Calibrated \\
Conductivity of HKZ & $\mathrm{K}_{6}(\mathrm{~m} /$ day $)$ & 2.16 & Calibrated \\
Conductivity of bed rock & $\mathrm{K}_{7}(\mathrm{~m} / \mathrm{day})$ & 0.000864 & See note \\
Compressibility of water & $\alpha\left(\mathrm{m} \mathrm{d}^{2} / \mathrm{kg}\right)$ & $5.89 \times 10^{-20}$ & See note \\
Compressibility of sand & $\beta_{1}\left(\mathrm{~m} \mathrm{~d}^{2} / \mathrm{kg}\right)$ & $2.68 \times 10^{-18}$ & See note \\
Compressibility of clay & $\beta_{2}\left(\mathrm{~m} \mathrm{~d}^{2} / \mathrm{kg}\right)$ & $5.36 \times 10^{-18}$ & See note \\
Compressibility of rock & $\beta_{3}\left(\mathrm{~m} \mathrm{~d}^{2} / \mathrm{kg}\right)$ & $1.34 \times 10^{-20}$ & See note \\
\hline
\end{tabular}

Note: A very low value was given to $K_{7}$ to represent the impermeable bottom; the values of the last 4 parameters were taken from typical values from the FEMWATER website (Reeve, 1998); Water retention curves for all layers were chosen from the GMS database. For speeding up model convergence, unsaturated conductivities were assumed to be linear functions of moisture content.

\section{DISCUSSION ON FACTORS AFFECTING GROUNDWATER HEADS}

Numerical simulations were conducted using the calibrated model to investigate how groundwater heads are affected by (1) the seasonal change in rainfall recharge; (2) rainfall recharge rate in Lantau Island; and (3) the hydraulic conductivity of the alluvial clay layer.

\subsection{Effect of seasonal change in rainfall recharge}

A transient simulation was run using the rainfall data in a typical year with a yearly rainfall of $2079 \mathrm{~mm}$ and the rainfall recharge coefficients specified in Table 1. The seasonal variations in groundwater heads of the three aquifers approximately at the center of the airport are shown in Figure 4. Groundwater heads at all aquifers follow the seasonal variation of rainfall. Groundwater head in the fill layer fluctuates closely with rainfall distribution, but there is a significant delay in the heads in the deep two aquifers in response to rainfall. The difference between the highest and lowest heads in a layer is over $2 \mathrm{~m}$. This may partly explain the discrepancy between observed and simulated heads using a steady state numerical model.

\subsection{Effect of the hydraulic conductivity of alluvial clay}

Two simulations were run using $50 \%$ and $200 \%$ of the original hydraulic conductivity value of the alluvial clay. The results (not shown here) indicate that the head difference between the fill layer and the alluvial aquifer is strongly affected by the hydraulic conductivity of the alluvial clay layer. The head difference shows a great seasonal variation and the fluctuation is much larger in the first half of a year than the second half. This suggests that the observed variation of point heads may be partly caused by the spatial variation in the hydraulic conductivity of the alluvial clay.

\subsection{Effect of rainfall recharge rate in areas outside of the airport}

To investigate how the vertical distribution of pressure heads below the airport may be affected by rainfall recharge in Lantau Island, a simulation was run by reducing rainfall recharge rates in Lantau Island to $50 \%$ of their original values. The simulation results show that pressure heads at all geological formations below the airport decrease due to less rainfall recharge from Lantau Island. Since the reduction in pressure head in the soil, especially in the alluvial clay, may potentially cause 


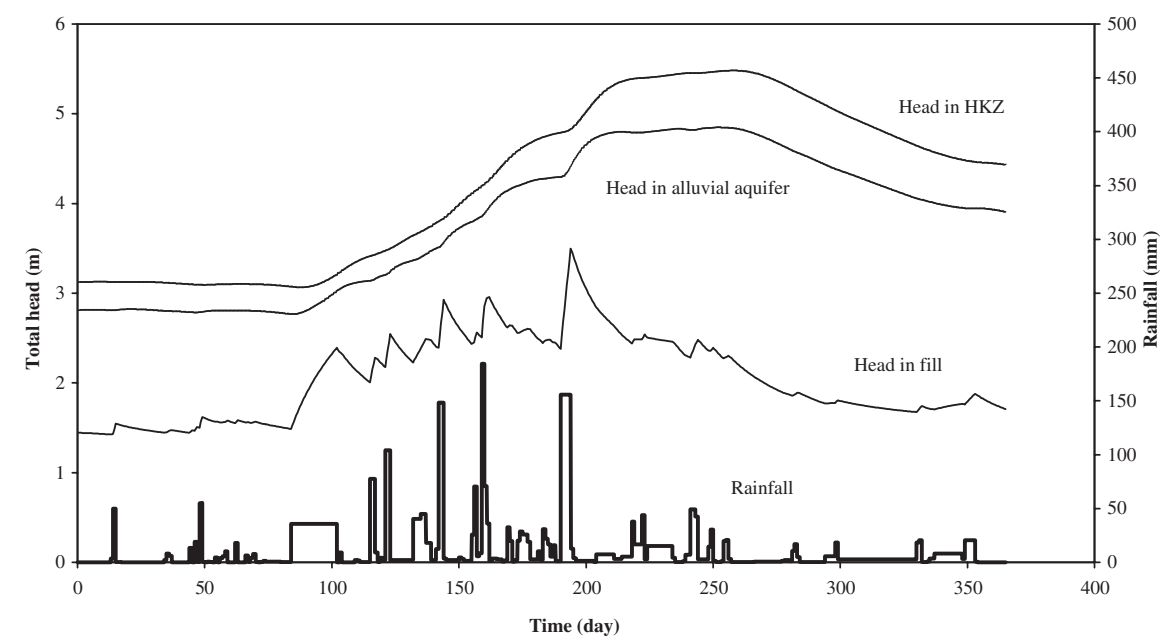

Figure 4. The effect of seasonal change in rainfall on groundwater heads in the three aquifers.

additional land subsidence in the airport, it is necessary to study the relationship between pressure head changes and rainfall recharge in the Lantau Island.

\section{SUMMARY}

Groundwater flow in the multi-layer aquifer system in Hong Kong Airport and its surrounding area was modeled using a finite-element numerical model. The study demonstrates that the abnormally high pore pressure in the basal sand and gravel aquifer and the vertical upward flow are caused by the regional groundwater flow initiated in the Lantau Island. Although the groundwater head in the shallow fill materials are sensitive to the local rain infiltration, the head changes in the deep aquifers are controlled largely by rainfall recharge in the Lantau Island. Therefore, any changes in the regional flow system in the Lantau Island, such as the reductions in rainfall recharge and lateral flow towards the airport due to land use or tunnel construction, may lead to a change in pore pressure in the airport. Further field observations and computer modeling study are necessary to confirm the preliminary finding of this study.

\section{ACKNOWLEDGEMENT}

The study is supported by the Hong Kong Research Grants Council (RGC) (HKU 710502).

\section{REFERENCES}

Jiao, J.J. and Nandy, S., 2001. Confined groundwater zone and slope instability in hillsides of weathered igneous rock in Hong Kong, Hong Kong Geologist, Vol 7, p31-37.

Jiao, J.J. and Tang, Z., 1999. An analytical solution of groundwater response to tidal fluctuation in a leaky confined aquifer, Water Resources Research, 35(3), p747-751.

Lin, H.J., Richards, D.R., Talbot, C.A., Yeh, G.T., Cheng, J.R., Cheng, H.P. and Jones, N.L., 1997. FEMWATER: A Three-Dimensional Finite Element Computer Models for Simulating Density-Dependent Flow and Transport in Variably Saturated Media, Technical Report CHL-97-12, U.S. Army Engineer Waterways Experiment Station, MS.

Plant, G.W., Covil, C.S. and Hughes, R.A. (editors), 1998. Site preparation for the new Hong Kong International Airport: Design, construction and performance of the airport platform, Thomas Telford, London.

Reeve, M., 1998. U of S FEMWATER Page, http://www.engr.usask.ca/ mjr347/gwres/fw21.html 